\title{
The Role of the Ethogram in Equitation Science
}

Carol Hall $^{1 *}$ and Camie Heleski ${ }^{2}$

${ }^{1}$ School of Animal, Rural and Environmental Sciences, Nottingham Trent University, Brackenhurst Campus, Southwell, Nottinghamshire NG25 0QF. UK.

* Corresponding author: Carol.hall@ntu.ac.uk

Tel: +44 (0) 1158485212

${ }^{2}$ Department of Animal Science, Michigan State University, East Lansing, USA.

\begin{abstract}
The development of a comprehensive ethogram that could be used to record the behaviour of the ridden horse in a range of different scenarios would provide a valuable resource for researchers within Equitation Science. However, the relevance of the behaviours included in such an ethogram and guidelines on how these behaviours should be interpreted need to be resolved before such a resource could be universally adopted. The aim of this review is to summarise and evaluate the ethograms used by researchers within Equitation Science to date, including comparisons between studies and information relating to additional measures taken. Evidence for behavioural interpretation based on equine social behaviour, qualitative behavioural assessment, physiological measures, specific situations and subjective assessment of 'rideability' is discussed with reference to the results and conclusions drawn by the authors of the studies included in the review. The behavioural signs of conflict between horse and rider and the potential sources of this conflict, including discomfort, pain, fear and frustration, are identified. To date the most common use of ridden horse ethograms has been in the evaluation of training methods and dressage performance, with the spotlight being on welfare concerns, in particular in relation to head and neck position. It is suggested that future work should include the development of ethograms that are relevant in other equestrian disciplines, where they have the potential to contribute to furthering understanding of the challenges faced by ridden horses and the behaviours associated with positive and negative responses to these. Although the association between specific behaviours and physiological measures was found to be inconsistent in many cases, and individual differences occurred, behavioural observation is still the primary means of evaluating the performance and welfare of the ridden horse. Consequently it is imperative to know what behaviours are important and why. By combining the evidence from the range of available sources it will be possible to get closer to an accurate interpretation of the meaning of different ridden horse behaviours. The evaluation of training methods and the adoption of appropriate performance criteria will only be possible when there is sufficient evidence on which to base these conclusions. .
\end{abstract}

Key words: ethogram, horse, behaviour, ridden, welfare, equitation 


\section{Introduction}

The need for conformity when recording the behaviour of the ridden horse has prompted researchers in equitation science to work towards developing an ethogram that would form a basis for future research. One limitation of research within equitation science to date has been the relatively low participant numbers from which to draw general conclusions. To address this issue and derive more robust conclusions from individual studies, the development of standardized definitions and recording protocols has been one of the main objectives of the International Society for Equitation Science (ISES) www.equitationscience.com. This has resulted in the publication of preliminary guidelines relating to standardized protocols including an evaluation of the use of ethograms within equitation science (Pierard et al., 2015). Examples of ethograms that can be considered as excellent models from which a ridden horse ethogram could be developed include those of McDonnell (2003), Waring (2003) and the Przewalski’s Horse Ethogram (Boyd and Houpt, 1994). A number of studies involving monitoring ridden horse behaviour have referred to one or more of these texts in the construction of the ethogram the authors have used (for example Visser et al., 2009; von Borstel et al., 2009).

In ridden work the locomotory behaviour of the horse (the behavioural state) is generally determined by the rider, with changes in speed and gait resulting from signals from the rider. An ethogram for monitoring ridden horse behaviour should include the means of recording the response of the horse to those signals both in terms of the ensuing behavioural state and associated behavioural events (Martin and Bateson, 1993), including the resultant movement patterns. A valid ethogram should include a comprehensive and clear descriptive list of behaviours observed in the ridden horse and include illustrations where possible (see Heleski et al., 2009). An unambiguous, detailed ethogram is required to record behavioural observations that enable the evaluation of training, equipment, rider and performance and allow inferences to be drawn regarding the welfare of the horse. For such behavioural observations to provide a meaningful evaluation of horse welfare, the implications for underlying mental state must also be considered. To facilitate this evaluation, behaviour associated with pain, discomfort, anxiety, fear and distress should be identified. This is achieved in part based on personal experience of researchers, but has been strongly supplemented by the use of the qualitative behavioural assessment method (QBA) (e.g. Fleming et al., 2013; Minero et al., 2009). It is also crucial that physiological measures, including heart rate / heart rate variability, ECG, changes in hormonal concentrations, respiration, surface and core temperature, sweat production and defaecation rate are included to support behavioural results (Hall et al., 2014).

The aim of this review is to evaluate the use of ethograms to provide an objective, evidence-based method of recording the behaviour of the ridden horse. Behaviour indicative of compromised welfare in the ridden horse will be identified, with particular reference to pain avoidance and escape behaviour. Such behaviour 
often conflicts with what the rider requires from the horse and is commonly referred to as 'conflict behaviour'. Where there is a lack of evidence to support behavioural interpretation, this will be addressed and the need for future work identified.

\section{Recording the behaviour of the ridden horse}

Behavioural responses of the ridden horse to a number of different factors have been recorded with reference to an ethogram. The range of behaviours included has largely depended upon the aim of the study and the nature of the factor(s) under investigation. In general, the aim of the majority of this research has been to identify factors that may compromise the welfare of the ridden horse and provide evidence to support changes in training, husbandry and potentially the criteria on which ridden horse performance is judged. The focus of a number of studies involving ridden horses has been on approaches to training, including comparisons between training methods described as 'conventional' or 'sympathetic' (Visser et al., 2009), behavioural reinforcement (Egenvall et al., 2012), the effect of training equipment (Heleski et al., 2009; Quick and Warren-Smith, 2009) and the impact of head/neck position on the horse (von Borstel et al., 2009).

The ethograms used in many of the ridden horse studies have been based on relatively few source texts. The most commonly referred to texts are Waring (2003) and McDonnell (2003), and this is wholly justified given the comprehensive and detailed information provided therein. Waring (2003) includes a list of 143 behaviours including motor patterns, postures, emissions and other behavioural states and events characteristic of the horse ethogram. Descriptions and in some cases, illustrations, are provided within the text and it is these descriptors that have often been used in subsequent studies. Waring (2003) refers the reader to the work of ethologists who have developed equine ethogram material with illustrations, including Feist and McCullough (1976) and McDonnell and Haviland (1995). McDonnell (2003) includes an extensive collection of descriptions, illustrations and photographs of equine behaviour with sections on maintenance behaviour, social communication, inter-male interaction, reproductive behaviour, play and domestically shaped and aberrant behaviour. The description and listing of all observed behaviours within a species has formed the basis of understanding the behaviour of that species and factors that influence it. . In all but the final section McDonnell (2003) includes illustrations that have been taken from observations of a managed, semi-feral herd and the main focus is on 'natural' horse behaviour. The impact of human management and training on the behaviour of the horse is briefly covered in the final section, where behaviour not generally observed in free-ranging horses is described (McDonnell, 2003). Studies investigating the effect of human interaction on the behaviour and welfare of the horse will generally use a sub-section of the overall ethogram, with behaviour relevant to the question posed by the researcher being 
identified (McDonnell, 2003). Such has been the case in the ridden horse studies where the focus thus far has been on the evaluation of potentially negative occurrences.

To facilitate consistency and rigour in the study of ridden horse behaviour and to clarify terms used to describe this, McGreevy et al. (2005) produced a text outlining the terms and processes involved in equitation. This was presented at the first meeting of the International Society for Equitation Science (Australia, 2005). This source has been referred to in the development of some of the subsequent studies involving ridden horses. See Table 1 for an overview of studies involving ridden horses that have included an ethogram. The source referred to in the development of the ethogram used in each study has been identified (if cited) in addition to the main question posed and the number of horses included in each study (these numbers represent the actual horses included in each study and do not take account of replication). In studies that have included physiological measures this has also been identified and will be referred to in Section 3.3 below.

\section{Table 1: Studies incorporating the use of an ethogram to monitor behaviour in ridden horses}

The level of descriptive detail of the horse behaviour that is included in each study, rider data and details of additional objective measures used are identified.

\begin{tabular}{|c|c|c|c|c|}
\hline $\begin{array}{l}\text { Study (including } \\
\text { main topic and } \\
\text { number of } \\
\text { horses) }\end{array}$ & $\begin{array}{l}\text { Horse behaviour and } \\
\text { source of ethogram }\end{array}$ & $\begin{array}{l}\text { Descriptive } \\
\text { detail of } \\
\text { behaviour }\end{array}$ & $\begin{array}{c}\text { Rider } \\
\text { behaviour / } \\
\text { objective } \\
\text { measures }\end{array}$ & $\begin{array}{c}\text { Physiological } \\
\text { measure } \\
\text { (horse) }\end{array}$ \\
\hline $\begin{array}{l}\text { de Cartier d'Yves } \\
\text { and Ödberg, } 2005 \\
\text { - subjective and } \\
\text { objective } \\
\text { assessment of } \\
\text { dressage } \\
\text { performance } \\
(\mathrm{N}=30)\end{array}$ & $\begin{array}{l}\text { Evasive behaviours: head } \\
\text { movement, ears, mouth, } \\
\text { gross movements: } \\
\text { rearing, bucking, jigging, } \\
\text { balking, bolting, backing. } \\
\text { No source cited. }\end{array}$ & $\begin{array}{l}\text { Behaviour and } \\
\text { description } \\
\text { (only } \\
\text { behaviour } \\
\text { classed as } \\
\text { evasive } \\
\text { included) }\end{array}$ & $\begin{array}{l}\text { Rein tension } \\
\text { monitored } \\
\text { using force } \\
\text { sensor on } \mathrm{R} \\
\text { rein. }\end{array}$ & $\begin{array}{l}\text { Heart rate } \\
\text { (Polar Horse } \\
\text { Trainer S- } \\
610 \text { ) }\end{array}$ \\
\hline $\begin{array}{l}\text { Egenvall et al., } \\
2012 \text { - training / } \\
\text { reinforcement } \\
(\mathrm{N}=4)\end{array}$ & $\begin{array}{l}\text { Head position and head } \\
\text { movement } \\
\text { Mouth open } \\
\text { No source cited. }\end{array}$ & $\begin{array}{l}\text { Behaviour } \\
\text { category, } \\
\text { specific } \\
\text { behaviour, } \\
\text { description, } \\
\text { illustration }\end{array}$ & $\begin{array}{l}\text { Hand } \\
\text { movements } \\
\text { described; } \\
\text { visible rein } \\
\text { tension }\end{array}$ & None \\
\hline $\begin{array}{l}\text { Hall et al., } 2014- \\
\text { comparison with } \\
\text { professional } \\
\text { assessment }\end{array}$ & $\begin{array}{l}\text { Head / neck position and } \\
\text { movement; ears; mouth; } \\
\text { tail; salivation; } \\
\text { vocalization. }\end{array}$ & $\begin{array}{l}\text { Behavioural } \\
\text { category, } \\
\text { specific }\end{array}$ & Not included & $\begin{array}{l}\text { Salivary } \\
\text { cortisol } \\
\text { Eye } \\
\text { temperature }\end{array}$ \\
\hline
\end{tabular}




\begin{tabular}{llll}
\hline$(\mathrm{N}=10)$ & $\begin{array}{l}\text { Source: } \text { Weeks } \text { 1996; } \\
\text { Kaiser } \text { et al. } 2006 ;\end{array}$ & behaviour, & using infrared \\
& Heleski et al. $2009 ;$ Hall & & thermography \\
& et al. 2012. & & (IRT)
\end{tabular}

\begin{tabular}{lllll}
\hline $\begin{array}{l}\text { Heleski et al., } \\
\text { 2009- effect of } \\
\text { martingales / rein }\end{array}$ & $\begin{array}{l}\text { Head / neck position and } \\
\text { movement; ears; mouth; } \\
\text { inserts }\end{array}$ & $\begin{array}{l}\text { Behavioural } \\
\text { category, } \\
\text { specific } \\
\text { behaviour } \\
\text { description, }\end{array}$ & $\begin{array}{l}\text { Hand height } \\
\text { Hand }\end{array}$ & None \\
& $\begin{array}{l}\text { Source for attribution as } \\
\text { conflict behaviour: }\end{array}$ & $\begin{array}{l}\text { Rein tension } \\
\text { monitored } \\
\text { illustration }\end{array}$ & \\
& $\begin{array}{l}\text { McDonnell 2003; } \\
\text { McLean and McLean }\end{array}$ & & transducers: \\
& 2002; de Cartier d'Yves & & MLP-75. \\
& Transducer \\
& McGreevy Ond al. 2005. & & Technologies) \\
\end{tabular}

\begin{tabular}{|c|c|c|c|c|}
\hline $\begin{array}{l}\text { Kaiser et al., } 2006 \\
\text { - impact of } \\
\text { therapeutic use on } \\
\text { horse behaviour } \\
(\mathrm{N}=14)\end{array}$ & $\begin{array}{l}7 \text { stress behaviours: head } \\
\text { toss, ears pinned back, } \\
\text { head raised, head down, } \\
\text { head shake, head turn, } \\
\text { defaecation. } \\
\text { Source: McDonnell } \\
\text { 2003, Waring 2003, } \\
\text { Houpt et al. 2000, Weeks } \\
\text { 1996. }\end{array}$ & $\begin{array}{l}\text { Behaviour, } \\
\text { description, } \\
\text { illustration } \\
\text { (stress } \\
\text { behaviours } \\
\text { only) }\end{array}$ & $\begin{array}{l}\text { Skill level } \\
\text { considered as } \\
\text { a factor but no } \\
\text { rider } \\
\text { behaviour } \\
\text { recorded }\end{array}$ & None \\
\hline $\begin{array}{l}\text { König von Borstel } \\
\text { et al. } 2011- \\
\text { objective } \\
\text { assessment of } \\
\text { equine personality } \\
(\mathrm{N}=36)\end{array}$ & $\begin{array}{l}\text { Head position / } \\
\text { movement, ear position, } \\
\text { vocalization, tail } \\
\text { swishing, gross } \\
\text { movements: change in } \\
\text { pace, buck, stumble, shy, } \\
\text { crabbing. } \\
\text { No source cited. }\end{array}$ & $\begin{array}{l}\text { Behaviour } \\
\text { category, } \\
\text { behaviour, } \\
\text { description. }\end{array}$ & $\begin{array}{l}\text { Visibility of } \\
\text { hand and leg } \\
\text { aids, use of } \\
\text { whip, voice, } \\
\text { transitions }\end{array}$ & $\begin{array}{l}\text { Heart rate / } \\
\text { heart rate } \\
\text { variability } \\
\text { (Polar } 800 \\
\text { XS) }\end{array}$ \\
\hline $\begin{array}{l}\text { Munsters et al. } \\
2012 \text { - horse-rider } \\
\text { match and } \\
\text { response to } \\
\text { challenging } \\
\text { objects } \\
(\mathrm{N}=16)\end{array}$ & $\begin{array}{l}\text { Behavioural scores based } \\
\text { on level of perceived } \\
\text { anxiety (10 point scale): } \\
\text { subjective assessment of } \\
\text { degree of relaxation, neck } \\
\text { elevation/position, ear } \\
\text { position, stride length, } \\
\text { speed. } \\
\text { Source: Visser et al. } \\
2010 \text {. }\end{array}$ & $\begin{array}{l}\text { Behavioural } \\
\text { description for } \\
\text { each level of } \\
\text { anxiety. }\end{array}$ & $\begin{array}{l}\text { Match with } \\
\text { horse based on } \\
\text { horse } \\
\text { behaviour } \\
\text { (Subjective } \\
\text { assessment - } \\
\text { Source: } \\
\text { McLean and } \\
\text { McGreevy } \\
\text { 2010) } \\
\text { Heart rate / } \\
\text { heart rate }\end{array}$ & $\begin{array}{l}\text { Heart rate / } \\
\text { heart rate } \\
\text { variability } \\
\text { (Polar-RS800) }\end{array}$ \\
\hline
\end{tabular}




\begin{tabular}{|c|c|c|c|c|}
\hline & & & $\begin{array}{l}\text { variability } \\
\text { (Polar-RS800) }\end{array}$ & \\
\hline \multirow{3}{*}{$\begin{array}{l}\text { Munsters et al. } \\
2013 \text { - workload / } \\
\text { stress associated } \\
\text { with police work } \\
(\mathrm{N}=9)\end{array}$} & \multirow{3}{*}{$\begin{array}{l}\text { Behavioural scores based } \\
\text { on level of perceived } \\
\text { anxiety (10 point scale): } \\
\text { subjective assessment of } \\
\text { degree of relaxation, neck } \\
\text { elevation/position, ear } \\
\text { position, stride length, } \\
\text { speed. } \\
\text { Source: Visser et al. } \\
\text { 2010; } \text { Munsters et al. } \\
2012 \text {. }\end{array}$} & \multirow[t]{3}{*}{$\begin{array}{l}\text { Behavioural } \\
\text { description for } \\
\text { each level of } \\
\text { anxiety. }\end{array}$} & \multirow{3}{*}{$\begin{array}{l}\text { Ability to } \\
\text { control fear } \\
\text { response of } \\
\text { horse } \\
\text { subjectively } \\
\text { assessed }\end{array}$} & $\begin{array}{l}\text { Heart rate / } \\
\text { speed of } \\
\text { locomotion } \\
\text { (Polar-RS800) }\end{array}$ \\
\hline & & & & $\begin{array}{l}\text { Plasma lactate } \\
\text { concentration }\end{array}$ \\
\hline & & & & \\
\hline \multirow{3}{*}{$\begin{array}{l}\text { Quick and } \\
\text { Warren-Smith } \\
2009 \text { - effect of } \\
\text { bit / bitless bridle } \\
\text { in preliminary } \\
\text { training } \\
(\mathrm{N}=4)\end{array}$} & \multirow{3}{*}{$\begin{array}{l}\text { Chewing, mouth opening, } \\
\text { ear movements, pawing } \\
\text { the ground, tail swishing, } \\
\text { head shaking, snorting, } \\
\text { yawning, bucking, } \\
\text { defaecating } \\
\text { Source: Waring } 2003\end{array}$} & \multirow{3}{*}{$\begin{array}{l}\text { Reference to } \\
\text { definitions in } \\
\text { Waring } 2003 \\
\text { but not } \\
\text { provided. }\end{array}$} & \multirow[t]{3}{*}{ Not included. } & $\begin{array}{l}\text { Heart rate / } \\
\text { heart rate }\end{array}$ \\
\hline & & & & $\begin{array}{l}\text { variability } \\
\text { (Polar) }\end{array}$ \\
\hline & & & & \\
\hline \multirow{2}{*}{$\begin{array}{l}\text { Rivera et al. } 2002 \\
- \text { effect of } \\
\text { housing on initial } \\
\text { training } \\
(\mathrm{N}=16)\end{array}$} & \multirow[t]{2}{*}{$\begin{array}{l}\text { Head/neck position, tail } \\
\text { position/movement, } \\
\text { bucking, jumping }\end{array}$} & \multirow[t]{2}{*}{$\begin{array}{l}\text { Behaviour } \\
\text { category and } \\
\text { description }\end{array}$} & \multirow{2}{*}{$\begin{array}{l}\text { No detail of } \\
\text { ridden } \\
\text { behaviour } \\
\text { provided } \\
\text { (behaviour } \\
\text { during } \\
\text { groundwork } \\
\text { described) }\end{array}$} & $\begin{array}{l}\text { Heart rate } \\
\text { (Polar } \\
\text { Vantage } \\
\text { NVTM) }^{\text {TM }}\end{array}$ \\
\hline & & & & $\begin{array}{l}\text { Plasma } \\
\text { cortisol }\end{array}$ \\
\hline \multirow{2}{*}{$\begin{array}{l}\text { Visser et al. } 2009 \\
\text { - evaluation of } \\
\text { different training } \\
\text { methods } \\
(\mathrm{N}=28)\end{array}$} & \multirow{2}{*}{$\begin{array}{l}\text { Head position and } \\
\text { movements, lip } \\
\text { movements, teeth } \\
\text { grinding, tail swishing, } \\
\text { body tension }\end{array}$} & $\begin{array}{l}\text { Each } \\
\text { behaviour } \\
\text { described }\end{array}$ & $\begin{array}{l}\text { Technical } \\
\text { performance } \\
\text { rated - horse }\end{array}$ & $\begin{array}{l}\text { Heart rate / } \\
\text { heart rate } \\
\text { variability }\end{array}$ \\
\hline & & $\begin{array}{l}\text { Source of } \\
\text { definition: } \\
\text { McDonnell } \\
\text { 2003; } \\
\text { McGreevy et } \\
\text { al. } 2005\end{array}$ & $\begin{array}{l}\text { response to } \\
\text { rider cues } \\
\text { (dressage } \\
\text { exercise) }\end{array}$ & \\
\hline \multirow{3}{*}{$\begin{array}{l}\text { von Borstel et al. } \\
2009-\text { Y-maze } \\
\text { preference test: } \\
\text { Rollkür / not } \\
\text { Rollkür } \\
(\mathrm{N}=15)\end{array}$} & \multirow{3}{*}{$\begin{array}{l}\text { Behavioural signs of } \\
\text { stress, discomfort, } \\
\text { frustration or conflict: } \\
\text { change in pace, bouts } \\
\text { backing up, crabbing, } \\
\text { bucks, stumbling, tail } \\
\text { swishing, head tossing, }\end{array}$} & $\begin{array}{l}\text { Each } \\
\text { behaviour } \\
\text { described }\end{array}$ & \multirow[t]{3}{*}{$\begin{array}{l}\text { Rider use of } \\
\text { whip / kicking } \\
\text { recorded }\end{array}$} & Heart rate \\
\hline & & $\begin{array}{l}\text { Source of } \\
\text { definition: }\end{array}$ & & \\
\hline & & $\begin{array}{l}\text { McGreevy et } \\
\text { al. 2005; }\end{array}$ & & \\
\hline
\end{tabular}




\begin{tabular}{lllll}
\hline & $\begin{array}{l}\text { nose tilting, abnormal } \\
\text { oral behaviour, snorting, } \\
\text { groaning, ears fixed } \\
\text { backwards, visibility of } \\
\text { eye white. }\end{array}$ & $\begin{array}{l}\text { Waring 2003; } \\
\text { Minero et al. } \\
2003 .\end{array}$ & \\
\hline Waite, 2014 & $\begin{array}{l}\text { Head position and } \\
\text { movements, ear } \\
\text { movements, tail swishing, } \\
\text { unrequested backing, } \\
\text { bucking, rearing, evasion }\end{array}$ & $\begin{array}{l}\text { Each behavior } \\
\text { described, } \\
\text { behavioral } \\
\text { category score } \\
\text { for entrance to } \\
\text { arena }\end{array}$ & $\begin{array}{l}\text { Jerking on } \\
\text { reins, } \\
\text { excessive } \\
\text { spurring, } \\
\text { excessive } \\
\text { kicking, use of } \\
\text { whip/crop/end } \\
\text { of reins }\end{array}$ & $\begin{array}{l}\text { Time for } \\
\text { completing } \\
\text { the } \\
\text { pattern }\end{array}$ \\
& & & & \\
\hline
\end{tabular}

\section{Evidence to support the interpretation of ridden horse behaviour}

\subsection{Social behaviour}

In order to accurately interpret behaviours in the ridden horse, researchers have made comparisons with natural horse behaviour / communication. McGreevy and McLean (2010) suggested that the nature of horsehuman interactions could be better understood by comparing these with natural horse-horse interactions and communication, but the value of this approach is dependent upon the accurate interpretation of observed behaviour. The proponents of 'natural horsemanship' training methods claim that these are based on intraspecies (horse-horse) communication and behaviour (for example, h Monty Roberts). A descriptive account of these methods has been critically evaluated by Farmer-Dougan and Dougan (1999). An experimental evaluation of horse behaviour in relation to the 'round pen technique' used by Monty Roberts was carried out by Krueger (2007). Specific behavioural events that have been associated with following behaviours in horses were recorded as a means of analyzing this approach to training, namely licking and chewing, stretching the head and neck down and ultimately following the trainer. The potential for mimicking the behaviour that horses use to establish dominance within their herd to facilitate horse training was investigated in a study carried out by Sighieri et al. (2003). Findings from this study, that involved five unhandled, free-ranging horses, led the authors to conclude that unhandled horses could be managed by mimicking their behaviour and that this approach would be beneficial in a training scenario. To date, features of equine social behaviour have predominantly been used to facilitate and assess training from the ground. However, the interpretation of ridden horse behaviour would also benefit from further reference to the equine social ethogram. The means by which the horse socially interacts and communicates have a role to play in constructing an ethogram that will facilitate the interpretation of ridden horse behaviour. Within 
a social group the horse is remarkably adept at communicating its 'feelings' to other group members. The skilled horseman can read these signs and respond appropriately. Comparisons between horse-horse and horse-human interactions may offer evidence on which behavioural interpretation can be based and McGreevy et al. (2009) conclude that increased integration of the equid social ethogram into riding and training techniques would be mutually beneficial to both horse and human.

\subsection{Qualitative Behavioural Assessment}

In general, previous studies that have used an ethogram to record the behaviour of the ridden horse have had the aim of evaluating how the horse is 'feeling' about what it is doing. An approach to evaluating precisely this aspect of animal behaviour has recently been applied in ridden horse studies. Qualitative Behavioural Assessment (QBA) is an approach that uses human observers to assess and score the behavioural expression of animals and employs a Free-Choice Profiling (FCP) methodology (Wemelsfelder et al., 2000; 2001). This method was used to evaluate the behavioural expression of horses during an endurance ride (Fleming et al., 2013). In this study it was found that observers reached consensus in their assessment of the horses' emotional state, reported consistent individual differences between horses (at whatever stage of the event they were observed), and assessed horses as being alert, curious and excited pre-ride and more tired, lazy and sleepy mid- and end-ride (Fleming et al., 2013). Since the study recorded only the observers' assessment of the horse's demeanor, the actual behaviour on which these assessments were based was not ascertained and without such information it is hard to incorporate the findings into guidelines for future evaluation. The study used observers who were experienced in horse handling and care, recruited from a group of animal and veterinary science students. The inter-observer consistency and the ability of the observers to detect differences in the behaviour of the horses that related to the stage of the endurance event suggests that there are behavioural indicators associated with the way the horse 'feels'. The relationship between qualitative (FCP) and quantitative behavioural observation was assessed in a study that evaluated the response of foals to handling training (Minero et al., 2009). By incorporating both qualitative and quantitative assessment of ridden horse behaviour, using experienced observers and an objective method of recording behaviour, behavioural signs associated with how the horse is thought to 'feel' could be identified. However, it has been shown that equestrian professionals may differ in their assessment of ridden horse behaviou, with differences in interpretation varying according to their professional role and personal experience (Hall et al., 2014). Consequently, more robust objective (physiological) evidence may be required to confirm the accuracy of behavioural interpretation and efficacy of the use of Qualitative Behavioural Assessment. 


\subsection{Physiological evidence}

The relationship between physiological responses, behavioural signs and underlying mental state can be inconsistent and potentially misleading. However, the search for an objective means of validating behavioural interpretation often results in comparisons being made between observed behaviour and physiological measures, for example those associated with signs of stress (including heart rate / heart rate variability, cortisol and eye temperature). Within the studies reported in this review, a number have identified considerable individual differences in behavioural response (Munsters et al. 2012; Heleski et al. 2009) and a lack of consistency between behaviour and physiological measures (König von Borstel et al. 2011; Munsters et al. 2012). In general, the confounding effects of exercise on these measures and the differentiation between physical and mental stress and physiological response, has resulted in mixed findings and the potential for some conclusions to be flawed. Even when exercise is not involved, these measures may not reliably provide evidence to enable accurate interpretation of behaviour. For example, increases in cortisol levels were found to have no association with behavioural responses during a stationary, handling procedure (clipping). Although some horses demonstrated avoidance / anxiety-related behaviour, their cortisol response was comparable to those horses that did not respond adversely to the procedure (Yarnell et al., 2013). In the ridden horse, increases in cortisol have been found to be associated with a lowered head and neck position (Hall et al., 2014) and hyperflexion of the head and neck (Zebisch et al., 2013). It is likely that this position is associated with higher physical exertion and this additional physical stress may account for the hormonal response. However, Young et al. (2012) found a significant correlation between behavioural indicators of stress in non-ridden scenarios and increased cortisol levels so further investigation is required.

Other physiological measures may provide evidence in relation to possible mental stress and therefore facilitate the interpretation of behavioural responses. For example, heart rate variability was found to correlate with behavioural signs of stress during low intensity exercise (Rietmann et al., 2004). Increases in eye temperature have been shown to relate to behavioural signs of anxiety during handling procedures (Hall et al., 2014) and in response to competitive show jumping (Valera et al., 2012). The value of changes in eye temperature as a means of interpreting behaviour is under review. Suffice to say that the relationship between behaviour, mental state and physiological response is a complex one. See Table 1 for details of the behaviour and physiological measures that were taken in thirteen of the studies discussed within this review. See also König von Borstel et al. (current edition/issue) for a review of stress parameters used within equitation science. 


\subsection{Situational evidence}

When the role of the ridden horse involves situations that are likely to be challenging, over and above the intrinsic challenge of carrying and being controlled by a human, the need to evaluate the impact on the horse becomes greater. The behaviour of horses within a ridden human therapeutic setting (including ridden sessions with 'at risk' children, as defined by their being at risk of poor performance / failure at school for specified reasons, including low socio-economic status, single parent family, record of disciplinary action) was assessed using an ethogram that included behavioural states (e.g. movement: backwards, halt, walk, trot, canter) and behavioural events (e.g. tail swish, head toss) (Kaiser et al., 2006). Of the behavioural events recorded, seven were listed as indicative of stress, irritation or frustration with descriptors modified from McDonnell (2003) and Waring (2003). These behaviours were: head toss, ears pinned back, head raised, head down, head shake, head turn and defecation. Behavioural events recorded but not considered as indicative of stress were ears turned (listening), moving tail, chomping bit, urination and whinnying. The mean number of stress-related behaviours recorded was found to be significantly greater when the horses were ridden by 'at risk' children (Kaiser et al., 2006). In terms of assessing ridden horses it may be deemed appropriate to include mouth movements in relation to the bit as possible signs of discomfort and then interpretation of tail movement would depend on the degree and type of movement. However, reference to this study in terms of identifying behavioural events suggestive of stress is made in other studies of ridden horse behaviour (for example, Heleski et al., 2009).

Anxiety in police horses during riot control training and night patrols was assessed using a ten-point scale whereby each level of anxiety was defined by listing the associated behaviour indicative of this state (Munsters et al., 2013). Behavioural events in this case related primarily to ear position, position of the head and neck and the speed and direction of movement in relation to an identified object. In addition to specified behavioural events, an evaluation of the level of relaxation, excitement or anxiety being shown by the horse was included in the scoring criteria. The behavioural responses of the horse in such situations provide a good starting point for the identification of behavioural signs of stress / distress in the ridden horse.

\subsection{Assessment of rideability}

The recording and evaluation of the behaviour of the ridden horse is less straightforward than recording/evaluating horse behaviour in more natural settings. During the ridden work the behaviour of the horse is, or at least should be, under the control / direction of the rider. Even if the horse is not under the rider's control, it is likely the rider is still influencing its behaviour. One aim of ridden horse research is to evaluate the response of the horse to signals from the rider. Consequently it is necessary, in most cases, to 
record rider behaviour at the same time as recording horse behaviour and also the synchrony between the two. As riders become more skilled and the horse becomes more responsive to the signals given, these signals may become less visible to the observer and so harder to record. In some cases a partial ethogram of rider behaviours has been developed to note its relationship with the behaviours expressed by the horse (e.g. Waite, 2014). Problems and inconsistencies associated with assessing the rider's seat were noted in the study Zetterqvist Blokhuis et al. (2008). Although the evasive behaviours of the horse were clearly visible (head toss, ears pinned, gaping mouth, tail swishing, bucking, rearing, shying: from De Cartier d'Yves and Ödberg, 2005) experienced trainers were inconsistent in their evaluation of the riders' seat. It was concluded that a more robust system was needed to enable robust evaluation of this aspect of rider performance (Zetterqvist Blokhuis et al., 2008).

Subjective evaluation of the 'rideability' of a horse is incorporated in performance testing for a number of horse breeds. The behaviour that results in a horse being scored highly for this 'rideability' is unclear, whether it be from the point of view of a judge, rider or observer. However, this trait is valued by judges during performance testing and in particular by riders (Górecka-Bruzda et al., 2011). Rideability can be defined as the degree of comfort experienced by the rider and the ease with which the horse can be ridden (Kőnig von Borstel and Glißman, 2014). To enable rideability to be assessed there is the need to consider the behaviour of both horse and rider and how the two interact König von Borstel and Glißman (2014) provide a list of behaviour patterns of horse and rider in addition to recording rein tension in order to evaluate this parameter as an objective measure for use during horse performance tests. The authors conclude that rein tension per se and the consistency of rein tension was an important factor in how rideability was assessed by judges on the ground. . In fact this was a better predictor of rideability assessment than horse behaviour. The behaviours that contributed most to these scores were tail swishing, use of the rider's hands, horse-induced changes of gait and shying (König von Borstel and Glißman, 2014). Some association between observed behaviour during an in-hand evaluation (at a field test for Danish Warmblood horses) and subjective evaluation by owners/riders of the horse's rideability was found by Rothmann et al. (2014), but no specific ridden behaviours were identified as being indicative of rideability.

\section{Behavioural signs of conflict between horse and rider}

The assessment of ridden horse behaviour must take into account what is desired by the rider and how the behaviour exhibited by the horse deviates from this. The desired behaviour will undoubtedly vary according to discipline, rider preferences, physical capability of both horse and rider, training level and numerous other factors. However, the need for evidence-based behavioural indicators that can reliably be used to assess the effectiveness of training and the ability of the horse to perform the movements as required is 
clear. The term 'conflict behaviour' has been used to describe the behavioural signs of mental and/or physical discomfort as demonstrated in response to handling / training cues by the horse (McGreevy et al., 2005). .

In the animal behaviour literature conflict behaviour refers to actions performed when two or more motivational systems are assumed to be aroused and cannot be expressed at the same time (Barnard, 2004). For example, a horse being ridden away from a group of horses would be motivated to stay in the 'herd' but also to respond to the rider's signal. Conflict behaviour in this case may include gross behavioural signs such as delayed movement, 'napping', failure to respond to the 'go' signal; or more subtle signs of conflict such as changes in facial expression and tail movements. Ideally, with appropriate training the motivation to respond to the rider's signals will override any other sources of behavioural motivation. However, when the training has been inappropriate for the behaviour requested, the horse is experiencing pain, discomfort and/or fear for any reason or the rider signals are unclear, 'unwanted' behavioural responses may occur. Such unwanted behavioural responses can be on a 'large' scale, often referred to as ridden behaviour problems (e.g. Hockenhull and Creighton, 2013) or 'smaller' scale which may be referred to as resistance to rider signals (Fédération Equestre Internationale, 2009).

The identification of factors that contribute to conflicting motivational forces is one of the main aims of most of the studies included in this review. For example, signs of pain and the motivation to avoid pain result in behavioural responses such as restlessness and agitation, dullness, depression, reluctance to move, abnormal weight distribution, tilted head carriage, dilated nostrils, fixed stare and/or head shaking (Ashley et al., 2005). A lowered head carriage has also been associated with pain avoidance (Ashley et al., 2005) as has high head and neck carriage (Lesimple et al., 2010). Reference to the Horse Grimace Scale (HGS) which has been developed as a means of assessing changes in facial expression that are known to be associated with pain in the horse would provide additional evidence of underlying causes of conflict behaviour in the ridden horse (Dalla Costa et al., 2014). Lateral differences in performance may well also be suggestive of underlying pain and avoidance thereof. For further discussion of the association between pain and ridden horse behaviour see Hall et al. (2012).

Fear will motivate the horse to flee from potential sources of harm and this innate behavioural response frequently conflicts with rider signals, in particular the 'stop' signal. Such escape / avoidance behaviours that conflict with rider signals and desired behaviour are commonly reported behavioural problems. In the survey carried out by Hockenhull and Creighton (2013) which assessed the prevalence of ridden behaviour problems in UK leisure horses, the highest occurrence was of shying, followed by moving off before asked when the rider is mounting, pulling / leaning on the bit, jogging when asked to walk and resisting slowing down when asked. Bolting and rushing towards jumps were also reported but were less prevalent 
behavioural problems (Hockenhull and Creighton, 2013). For a review of tests and responses related to fear in horses see also Forkman et al. (2007).

Specific reference to conflict behaviour is made in a number of the more recent publications involving ridden horse behaviour. The nature of the conflict behaviour reported differs according to the ridden task or discipline concerned. Górecka-Bruzda et al. (2015) compared conflict behaviour in elite show jumping and dressage horses. In both cases the frequency of the conflict behaviour recorded increased as the difficulty of the task increased. The most frequent form of conflict behaviour exhibited by the show jumping horses was pulling the reins out of the rider's hands and this occurred most frequently during the approach to vertical and combination fences. Head shaking, gaping and tail swishing occurred most frequently during the approach to vertical fences. The dressage horses only consistently exhibited tail swishing and that most frequently during canter pirouette to the left, least frequently during the extended walk (Górecka-Bruzda et al., 2015). The impact of head / neck position on the exhibition of conflict behaviour by dressage horses was investigated by Kienapfel et al. (2014). Conflict behaviours recorded were tail swishing, ears fixed back, head tossing, mouth wide open, showing teeth, abnormal oral behaviour, nose tilting, going-against reins, change in gait, crabbing (horse not moving straight) and attempts to buck. These were combined to form one measure referred to as conflict behaviour which was found to occur significantly more in the horses ridden with their nasal plane behind the vertical and in horses competing at higher levels of dressage. Variation in individual behaviours was also assessed (Kienapfel et al., 2014).

The majority of research into the nature of conflict behaviour in ridden horses has to date focused on dressage and flatwork, often with an emphasis on the impact of specific training methods, in particular the position of the head and neck. The behaviour of horses when jumping has also featured, although the use of an ethograms to record behaviour of horses when negotiating obstacles is less common. Jumping performance is primarily judged by the clearance of the obstacle per se, with the associated behaviour being irrelevant. However, in order to understand the challenges faced by the horse in relation to negotiating obstacles at speed in equestrian sports such as eventing and racing, and to reduce the risk of injury or death to horses participating in such sports, furtherstudy of jumping behaviour is required.

Other equestrian sports will also benefit from devising relevant ethograms to record the occurrence of behaviour indicative of conflict, stress and irritation. An example of this can be found in relation to barrel racing (Waite, 2014). The ethogram used to record the impact of rider behaviour on that of the horse was developed from Kaiser et al. (2006). The behaviours recorded included generic signs of conflict (head toss, head shake, ears pinned back, tail lash / swish) and also specific signs that the horse was not responding to rider signals (moving backwards when asked to move forwards, rear, buck). All of the behaviours listed in the Cloverleaf Barrel Race Ethogram (Waite, 2014) have been identified as conflict behaviours in other 
equestrian disciplines but the source of this conflict and the underlying mental state associated with specific behavioural signs requires further investigation.

The identification of a specific behavioural event as a 'conflict behaviour' relies upon evidence that there exists conflicting motivation. It is often unclear as to whether signs of frustration and/or irritation shown by the horse are truly representative of conflict between two opposing motivation systems. When pain avoidance or escape behaviour is involved then there could undoubtedly be conflict with rider requirements. Behaviour that is associated with discomfort may be caused by the rider, in particular through inappropriate rein tension. An association between higher rein tension and increased head-related conflict behaviour was found in unridden horses in a study by Christensen et al. (2011). These behaviours consisted of fighting the rein, gaping (open mouth: space visible between upper and lower jaws) in combination with lifting and/or tilting the head. However, a behaviour that is commonly referred to as a sign of conflict and/or resistance is tail swishing and this was not recorded (Christensen et al., 2011). It could be argued however that in this study the main conflict was associated with trying to reach food against the discomfort of a tight rein and the lack of tail swishing could be explained by the fact that the mouth was the location of the discomfort. Tail swishing is commonly cited as a sign of negative mental state in the horse (see Tables 1 and 2) but Rietmann et al. (2004) found poor correspondence between tail swishing and physiological signs of mental stress (HRV and HR). Tail swishing was found to be associated with dressage horses competing at a high level (Prix St. Georges and Grand Prix) but not with those competing at Preliminary level (Williams and Warren-Smith, 2010). Similarly, Górecka-Bruzda et al. (2015) reported tail swishing when horses were completing complex movements in dressage or approaching challenging jumps in show jumping. Hall et al. (2014) found an association between the frequency of tail swishing and increases in salivary cortisol concentration. Tail swishing cannot be definitively used as an indicator of negative mental state or resistance, but may in fact relate to higher effort and concentration on the part of the horse. Although many studies base the interpretation of ridden horse behaviour on either physiological evidence and/or the results of as previous peer reviewed research, inconsistencies are still apparent. Table 2 identifies studies where the authors report specific behaviours that they interpret as being indicative of mental state along with the evidence on which they based their interpretation.

Table 2: Results of studies: Specific ridden behaviours and interpretation by authors (evidence for interpretation identified below*)

\begin{tabular}{clll}
\hline \multicolumn{1}{c}{ Study } & Behaviour & Interpretation & Evidence \\
\hline $\begin{array}{l}\text { de Cartier d'Yves } \\
\text { and Ödberg, 2005 }\end{array}$ & $\begin{array}{l}\text { Rearing, jigging, } \\
\text { balking, bucking, } \\
\text { running away, bolting, }\end{array}$ & Evasive behaviours & $\begin{array}{l}\text { Subjective scoring } \\
\text { (by dressage judges) } \\
\text { negatively }\end{array}$ \\
\hline
\end{tabular}




\begin{tabular}{|c|c|c|c|}
\hline & $\begin{array}{l}\text { head movement, tail } \\
\text { wringing, ear flattening, } \\
\text { sneezing, rooting } \\
\text { /gnashing at bit, gaping, } \\
\text { lip/tongue movement, } \\
\text { tongue over bit, } \\
\text { grinding teeth, locked } \\
\text { jaw }\end{array}$ & & $\begin{array}{l}\text { correlated with } \\
\text { frequency of } \\
\text { evasive behaviour) } \\
\text { - not related to } \\
\text { specific behaviour. }\end{array}$ \\
\hline \multirow[t]{3}{*}{ Egenvall et al., 2012} & $\begin{array}{l}\text { Head tilt / head shake }{ }^{1} \\
\text { Open mouth }{ }^{1}\end{array}$ & $\begin{array}{l}\text { Pushing against bit } \\
\text { pressure / relief from bit } \\
\text { pressure }\end{array}$ & $\begin{array}{l}\text { Link to rein pressure } \\
\text { from rider }\end{array}$ \\
\hline & Low head ${ }^{2}$ & Relaxation & $\begin{array}{l}\text { McLean and } \\
\text { McGreevy (2004) }\end{array}$ \\
\hline & High head ${ }^{2}$ & $\begin{array}{l}\text { Physiological response } \\
\text { when slowing down }\end{array}$ & $\begin{array}{l}\text { de la Guérinière } \\
\text { (1733) }\end{array}$ \\
\hline \multirow[t]{4}{*}{ Hall et al., 2014} & Low head carriage $^{1}$ & $\begin{array}{l}\text { Increased demands on } \\
\text { horse }\end{array}$ & $\begin{array}{l}\text { Increase in salivary } \\
\text { cortisol } \\
\text { concentration }\end{array}$ \\
\hline & $\begin{array}{l}\text { Nasal plane behind } \\
\text { vertical }^{1}\end{array}$ & $\begin{array}{l}\text { Increased demands on } \\
\text { horse }\end{array}$ & $\begin{array}{l}\text { Increase in eye } \\
\text { temperature }\end{array}$ \\
\hline & Nasal plane in front of & $\begin{array}{l}\text { Decreased demands on } \\
\text { horse }\end{array}$ & $\begin{array}{l}\text { Decrease in eye } \\
\text { temperature }\end{array}$ \\
\hline & Tail swishing ${ }^{1}$ & $\begin{array}{l}\text { Increased demands on } \\
\text { horse }\end{array}$ & $\begin{array}{l}\text { Associated with } \\
\text { increase in salivary } \\
\text { cortisol } \\
\text { concentration }\end{array}$ \\
\hline \multirow[t]{2}{*}{ Heleski et al. 2009} & Head position / height & $\begin{array}{l}\text { Lowered by martingale } \\
\text { use }\end{array}$ & \\
\hline & $\begin{array}{l}\text { Individual horses } \\
\text { showed variation in } \\
\text { amount of head toss, } \\
\text { head bob, head tilt, head } \\
\text { turn, chomping of / } \\
\text { gaping at bit, tail } \\
\text { swishing }^{2}\end{array}$ & Conflict behaviours & $\begin{array}{l}\text { McDonnell 2003; } \\
\text { McLean and } \\
\text { McLean 2002; de } \\
\text { Cartier d'Yves and } \\
\text { Ödberg 2005; } \\
\text { McGreevy et al. } \\
2005 \text {. }\end{array}$ \\
\hline Kaiser et al., 2006 & $\begin{array}{l}\text { Head toss, ears pinned } \\
\text { back, head raised, head } \\
\text { down, head shake, head } \\
\text { turn, defaecation }{ }^{2}\end{array}$ & Stress behaviours & $\begin{array}{l}\text { McDonnell 2003, } \\
\text { Waring 2003, Houpt } \\
\text { et al. 2000, Weeks } \\
\text { 1996. }\end{array}$ \\
\hline
\end{tabular}




\begin{tabular}{|c|c|c|c|}
\hline $\begin{array}{l}\text { König von Borstel et } \\
\text { al. } 2011\end{array}$ & $\begin{array}{l}\text { Head tossing, unasked } \\
\text { for gait change, tail } \\
\text { swishing } \\
\text { Nasal plane behind } \\
\text { vertical }\end{array}$ & $\begin{array}{l}\text { Relate to rider } \\
\text { assessment of decreased } \\
\text { ride-ability } \\
\text { Increased ride-ability / } \\
\text { personality }\end{array}$ & $\begin{array}{l}\text { No association } \\
\text { between HR/HRV } \\
\text { and behaviour of } \\
\text { horse } \\
\text { Rider ratings }\end{array}$ \\
\hline Munsters et al. 2012 & $\begin{array}{l}\text { Subjective assessment } \\
\text { of degree of relaxation, } \\
\text { neck elevation/position, } \\
\text { ear position, stride } \\
\text { length, speed }{ }^{2} \\
\text { Individual differences in } \\
\text { behavioural response to } \\
\text { challenging object }\end{array}$ & $\begin{array}{l}\text { Level of anxiety } \\
\text { Match with rider }\end{array}$ & $\begin{array}{l}\text { Visser et al. } 2010 \text {. } \\
\text { No association } \\
\text { between anxiety } \\
\text { behaviour score and } \\
\text { heart rate. }\end{array}$ \\
\hline Munsters et al. 2013 & $\begin{array}{l}\text { As above - no specific } \\
\text { behaviour identified. } \\
\text { Fear response (ears laid } \\
\text { back, flees from object) } \\
\text { worst when secluded } \\
\text { from con-specifics. }\end{array}$ & Fear of seclusion & $\begin{array}{l}\text { Subjective scoring } \\
\text { (Visser et al. 2010; } \\
\text { Munsters et al. } \\
\text { 2012) } \\
\text { Highest mean heart } \\
\text { rate in seclusion } \\
\text { exercise. }\end{array}$ \\
\hline $\begin{array}{l}\text { Quick and Warren- } \\
\text { Smith } 2009\end{array}$ & $\begin{array}{l}\text { Increase in head shaking } \\
\text { Increased tail swishing }\end{array}$ & $\begin{array}{l}\text { Bitless bridle } \\
\text { Bitted bridle }\end{array}$ & $\begin{array}{l}\text { No statistical } \\
\text { analyses but } \\
\text { descriptive } \\
\text { differences between } \\
\text { bit / bitless in } \\
\text { behaviours listed. } \\
\text { No specific } \\
\text { association between } \\
\text { HR/HRV and } \\
\text { behaviour reported. }\end{array}$ \\
\hline Rivera et al. 2002 & $\begin{array}{l}\text { Increased bucking / } \\
\text { jumping } \\
\text { Normal tail carriage }\end{array}$ & $\begin{array}{l}\text { Housed in individual } \\
\text { stalls } \\
\text { More frequent in pasture } \\
\text { housed horses }\end{array}$ & $\begin{array}{l}\text { No specific } \\
\text { association between } \\
\text { HR/HRV, plasma } \\
\text { cortisol } \\
\text { concentration and } \\
\text { behaviour reported. }\end{array}$ \\
\hline Visser et al. 2009 & $\begin{array}{l}\text { Low body tension, } \\
\text { medium head carriage, } \\
\text { less lip movement }{ }^{1}\end{array}$ & Reduced stress & Lower heart rate \\
\hline $\begin{array}{l}\text { von Borstel et al. } \\
2009\end{array}$ & $\begin{array}{l}\text { Stumbling }^{1} \\
\text { Backing up }\end{array}$ & $\begin{array}{l}\text { Low arousal } \\
\text { Avoidance }\end{array}$ & $\begin{array}{l}\text { Lower heart rate } \\
\text { Higher heart rate }\end{array}$ \\
\hline
\end{tabular}




\begin{tabular}{|c|c|c|c|}
\hline & $\begin{array}{l}\text { Change of pace, } \\
\text { crabbing, attempted } \\
\text { bucks, head tossing, } \\
\text { nose tilting, abnormal } \\
\text { oral behaviour, tail } \\
\text { swishing }\end{array}$ & Resistance & $\begin{array}{l}\text { More frequent use } \\
\text { of legs, whip by } \\
\text { rider }\end{array}$ \\
\hline \multirow[t]{2}{*}{ Waite, 2014} & $\begin{array}{l}\text { Aggressive rider } \\
\text { behaviors }\end{array}$ & $\begin{array}{l}\text { Did not result in faster } \\
\text { run times }\end{array}$ & $\begin{array}{l}\text { Waite and Heleski } \\
\text { worked together to } \\
\text { develop ethogram of } \\
\text { horse and rider } \\
\text { behaviors, and gate } \\
\text { score categories. }\end{array}$ \\
\hline & & & Kaiser et al., 2006 \\
\hline
\end{tabular}

*Basis of behavioural interpretation:

${ }^{1}$ Behavioural interpretation based on physiological (or other objective) evidence

${ }^{2}$ Behavioural interpretation based on peer reviewed research

\section{Behavioural signs of positive mental state in ridden horses}

Although the need to recognize signs of positive emotional state in animals has been acknowledged by those aiming to improve welfare in general (see for example, Boissy et al., 2007), identifying behaviour indicative of positive emotion in the ridden horse is problematic. The Fédération Equestre Internationale (FEI) rules for dressage events describe features of the happy equine athlete as being calm, supple, loose and flexible, but also confident, attentive and keen (FEI, 2009). No specific behavioural events are identified as being signs of positive mental state, although those attributable to signs of resistance (conflict behaviours) are described (FEI, 2009). Within the ethograms reviewed there is also a paucity of reference to potential behavioural evidence of positive mental state. It is likely that the evaluation of facial expression in the horse, as detailed in EquiFACS (a Facial Action Coding system for the domestic horse; Wathan et al., 2015), will provide a means of identifying positive as well as negative underlying mental state. The potential for combining the evidence of movement patterns, behavioural responses to rider signals and changes in facial expression, should enable the recognition of positive emotion in the ridden horse.

\section{The future role for ethograms in Equitation Science and equestrian sport}

The accurate and consistent recording of ridden horse behaviour requires the development of an evidence based ethogram that lists and comprehensively defines behaviours relevant to the discipline being studied 
and can identify signs of conflict from whatever source. The ethograms used to date generally incorporate behavioural states, which in the ridden horse relate to the speed and direction of movement, gait and whether this is initiated by the rider or determined by the horse. The largely subjective evaluation of movement patterns and their relationship to rider signals forms the basis of performance assessment in the equestrian discipline of dressage. In this sport, the FEI rules for dressage events provide descriptions of behaviour that should be aspired to and that form the basis of performance assessment (Fédération Equestre Internationale, 2009). The debate that ensued surrounding the welfare implications of training horses in a way that involved hyperflexion of the head and neck (Rollkür) resulted in a number of studies that aimed to investigate the impact that this form of training had on the horse (for example, von Borstel et al., 2009; Zebisch et al., 2013; Kienapfel et al., 2014). Current ridden horse ethograms consequently often include details of head and neck position, in addition to other behavioural events associated with ear, mouth and tail movements. The potential for movement patterns to be assessed objectively using gait analysis systems may result in less subjective scoring of performance in dressage in the future. However, the relationship between gait parameters and the regularity of paces, lightness and cadence that are the qualities sought within dressage are yet to be fully determined (Biau and Barrey, 2004). Biomechanical analysis and anatomical modeling techniques have been applied to quantify head and neck position and to determine the optimum position and the impact on movement (Elgersma et al., 2010; Rhodin et al., 2005). These objective measures will inform future assessment criteria, promote sustainable performance and improve ridden horse welfare. The risks associated with the sport of eventing have raised concerns in relation to the occurrence of horse injuries and fatalities, in particular during the cross country jumping phase. Since 2002 the FEI has been recording the statistics associated with falls, injuries and fatalities in the sport. The overall percentage of falls during 2014 (for all levels) was 5.59\%, slightly higher than 2013 (5.26\%) (FEI Eventing Risk Management Programme, published 09 February 2015). Measures taken to improve the safety records within the sport have mainly focused on jump design but future research into the behaviour of the horse during the approach to obstacles may provide further insight into contributory horse-rider related factors. In particular, head / neck position and movement during the approach to jumps may be predictive of how well the horse can see the jump and consequently its clearance. The behavioural events identified by Górecka-Bruzda et al. (2015) as being indicative of conflict during approaches to jumps involved movements of the horse's head and/or neck (including pulling the reins out of the rider's hands, head shaking and gaping). Such behaviour is likely to interfere with visual assessment and may result in visual misjudgment and jumping errors. The relationship between behavioural events and performance in equestrian sport requires further investigation. In all likelihood, Qualitative Behavioural Assessment (QBA) has an important role to play in helping interpret the affect behind observed behaviours in the ridden horse. However, there is a need for continued research comparing behaviours, conducting QBAs of said situations, and coupling with physiological 
evidence (e.g. heart rate, heart rate variability, cortisol levels, changes in eye temperature). By identifying the behaviours that are associated with QBA in specific scenarios (as in Minero et al., 2009) and comparing with underlying physiological measures, a unified approach based on different measures is the most likely way of arriving at an accurate interpretation of ridden horse behaviour.

One of the main limitations of the behavioural study of horse in a ridden scenario is the low participant numbers associated with most findings. This is in part due to practical limitations and access to large numbers of horses and riders under comparable situations. Coupled with the time needed to observe and analyse behavioural data, in addition to the potential for both inter- and intra-observer variability in what is recorded, the need for a more objective time-efficient, evidence-based system is clear. Movement patterns of the horse can be quantified and the task ahead is to identify parameters suggestive of movement quality. Once a comprehensive descriptive list of behavioural events associated with ridden behaviour is compiled there would then be the potential for the development of an automated image-based tracking system similar to that proposed by Dell et al. (2014) for applications in ecology.

In addition to recording behaviour during ridden work, the potential impact of training and performance on general welfare has been assessed using ethograms to assess time budgets and temperament (Innes and McBride, 2008). Ridden work cannot be considered in isolation but must be assessed on the basis of the effect that this may have on overall well-being. In addition, the impact of management and husbandry systems on training, performance and mental state should be considered (for example, Søndergaard and Ladewig, 2004). Chronic stress will impact on all aspects of life and may result in behaviour comparable to that associated with human depression (Hall et al., 2008; Fureix et al., 2012). To enable us to develop training and husbandry methods that promote well-being in the horse we need to identify positive behavioural signs, akin to evidence of positive affective state. From the results of their study involving preference testing in horses for short or long bouts of riding, König von Borstel and Keil (2012) tentatively suggest that some horses showed little aversion to and possibly some enjoyment of being ridden (König von Borstel and Keil, 2012). The relationship between expressions of anticipatory behaviour and reward sensitivity has been used as a means of assessing welfare in animals including the horse (Peters et al., 2012) and this may be an approach that could be adapted to assess the horse's attitude towards and enjoyment of ridden work.

\section{Conclusion}


The ethograms used within equitation science have been derived from a relatively small number of sources. Although there is some consistency in relation to the behaviours that are considered signs of affective state in ridden horses it is unlikely that conclusions based on behaviour alone will suffice. The search for quantitative, objective, often physiological evidence to support behavioural interpretation is ongoing. Inconsistent findings and a lack of association between measures has resulted in relatively unsubstantiated conclusions being drawn in some cases and tentative suggestions put forward to explain findings. However, the search for evidence to facilitate appropriate and accurate interpretation of ridden horses continues. There is never going to be a direct association between specific behavioural signs and the subjective experience of the horse as they are individuals who, just as is the case with humans, display signs of pleasure and distress differently. Individual differences aside, there are likely to be generic behavioural signs that can be identified by applying a combination of the approaches discussed in this review. As evidence in relation to behavioural interpretation is gained the findings must then be disseminated to the equestrian community and incorporated into guidelines and judging criteria for the various equestrian disciplines. Behavioural observation is the primary means of evaluating the performance and welfare of the ridden horse so it is imperative that significant behaviours are recognised and their implications for underlying mental state acknowledged. Only then will it be possible to accurately interpret what the horse is communicating when ridden and to respond accordingly. The improved welfare of all ridden horses is dependent upon increasing the accuracy with which their behaviour when ridden is understood. 


\section{References}

Ashley, F.H., Waterman-Pearson, A.E., Whay, H.R., 2005. Behavioural assessment of pain in horses and donkeys: application to clinical practice and future studies. Equine Veterinary Journal. 37, 565-575.

Barnard, C., 2004. Animal Behaviour: Mechanism, Development, Function and Evolution. Pearson Education Ltd., Harlow, Essex, UK. Pp: 192.

Biau, S., Barrey, E., 2004. Relationship between stride characteristics and scores in dressage tests. Pferdehelkunde. 20, 140-144.

Boissy, A., Manteuffel, G., Jensen, M.B., Moe, R.O., Spruijt, B., Keeling, L.J. Winckler, C., Forkman, B., Dimitrov, I., Langbein, J., Bakken, M., Veissier, I., Aubert, A. 2007. Assessment of positive emotions in animals to improve their welfare. Physiology and Behavior. 92. 375-397.

Boyd, L., Houpt, K.A., 1994. Przewalski's Horse: the History and Biology of an Endangered Species. State University of New York Press, Albany. Pp 195-227.

Christensen, J.W., Zharkikh, T.L., Antoine, A., Malmkvist, J., 2011. Rein tension acceptance in young horses in a voluntary test situation. Equine Veterinary Journal. 43, 223-228.

Dalla Costa, E., Minero, M., Lebelt, D., Stucke, D., Canali, E., Leach, M., 2014. Development of the Horse Grimace Scale (HGS) as a pain assessment tool in horses undergoing routine castration. PLOS ONE 9 (3): e92281.

de Cartier d'Yves, A., Ödberg, F.O., 2005. A preliminary study on the relation between subjectively assessing dressage performances and objective welfare parameters. In: Proceedings of the First International Equitation Science Symposium, Melbourne, Australia. Pp 89-110.

de la Guérinière, F.T., 1733. École de Cavalerie (School of Horsemanship, 1994; translated by Tracy Boucher). J.A. Allen, London, UK. P91.

Dell, A.I., Bender, J.A., Branson, K., Couzin, I.D., de Polavieja, G.G., Noldus, L.P.J.J., Pérez-Escudero, A., Perona, P., Straw, A.D., Wikelski, M., Brose, U., 2014. Automated image-based tracking and its application in ecology. Trends in Ecology and Evolution. 29, 417-428.

Egenvall, A., Eisersiö, M., Roepstorff, L., 2012. Pilot study of behaviour responses in young riding horses using two methods of making transitions from trot to walk. Journal of Veterinary Behaviour. 7, 157-168.

Elgersma, A.E., Wijnberg, I.D., Sleutjens, J., van der Kolk, J.H., van Weeren, P.R., Back, W., 2010. A pilot study on objective quantification and anatomical modeling of in vivo head and neck positions commonly applied in training and competition of sport horses. Equine Veterinary Journal 42 (Supplement 38) 436-443.

Farmer-Dougan, V.A., Dougan, J.D., 1999. The man who listens to behaviour: Folk wisdom and behaviour analysis from a real horse whisperer. Journal of the Experimental Analysis of Behavior. 72, 139-149.

Fédération Equestre Internationale, 2009. FEI Rules for Dressage Events, $23^{\text {rd }}$ Ed. Fédération Equestre Internationale, Lausanne, Switzerland. 
Feist, J.D., McCullough, D.R., 1976. Behavior patterns and communication in feral horses. Z. Tierpsychol. 41, 337-371.

Fleming, P.A., Paisley, C.L., Barnes, A.L., Wemelsfelder, F., 2013. Application of Qualitative Behavioural Assessment to horses during an endurance ride. Applied Animal Behaviour Science. 144, 8088.

Forkman, B., Boissy, A., Meunier-Salaún, M.-C., Canali, E., Jones, R.B., 2007. A critical review of fear tests used on cattle, pigs, sheep, poultry and horses. Physiology and Behavior. 92, 340-374.

Fureix, C., Jego, P., Henry, S., Lansade, L., Hausberger, M., 2012. Towards an ethological animal model of depression? A study on horses. PLoS ONE 7(6): e39280. doi: 10.1371/journal.pone.0039280

Górecka-Bruzda, A., Chruszczewski, M.H., Jaworski, Z., Golonka, M., Jezierski, T., 2011. Looking for an ideal horse: Rider preferences. Anthrozoos. 24, 379-392.

Górecka-Bruzda, A., Kosińska, I., Jaworski, Z., Jezierski, T., Murphy, J., 2015. Conflict behaviour in elite show jumping and dressage horses. Journal of Veterinary Behaviour. 10, 137-146.

Hall, C., Goodwin, D., Heleski, C., Randle, H., Waran, N., 2008. Is there evidence of learned helplessness in horses? Journal of Applied Animal Welfare Science. 11, 249-266.

Hall, C., Huws, N., White, C., Taylor, E., Owen, H., McGreevy, P.D., 2012. Assessment of ridden horse behaviour. Journal of Veterinary Behaviour. 8, 62-73.

Hall, C., Kay, R., Yarnell, K., 2014. Assessing ridden horse behaviour: Professional judgment and physiological measures. Journal of Veterinary Behaviour. 9, 22-29.

Heleski, C.R., McGreevy, P.D., Kaiser, L.J., Lavagnino, M., Tans, E., Bello, N., Clayton, H.M., 2009. Effects on behavior and rein tension on horses ridden with or without martingales and rein inserts. The Veterinary Journal. 181, 56-62.

Hockenhull, J., Creighton, E., 2013. The use of equipment and training practices and the prevalence of owner-reported ridden behaviour problems in UK leisure horses. Equine Veterinary Journal. 45, 15-19.

Houpt, K.A., Eggleston, A., Kunkle, K., Houpt, T.R., 2000. Effect of water restriction on equine behaviour and physiology. Equine Veterinary Journal. 32, 341-344.

Innes, L. McBride, S., 2008. Negative versus positive reinforcement: An evaluation of training strategies for rehabilitated horses. Applied Animal Behaviour Science. 112, 357-368.

Kaiser, L., Heleski, C.R., Siegford, J. and Smith, K.A., 2006. Stress-related behaviours among horses used in a therapeutic riding program. JAVMA. 228, 39-45.

Kienapfel, K., Link, Y., König von Borstel, U., 2014. Prevalence of different head-neck postions in horses shown at dressage competitions and their relation to conflict behaviour and performance marks. PLoS ONE. 9 (8), e103140. 
König von Borstel, U., Glißman, C., 2014. Alternatives to conventional evaluation of rideability in horse performance tests: Suitability of rein tension and behavioural parameters. PLoS ONE. 9, e87285.

König von Borstel, U., Keil, J., 2012. Horses' behaviour and heart rate in a preference test for shorter and longer riding bouts. Journal of Veterinary Behavior. 7, 362-374.

König von Borstel, U., Pasing, S., Gauly, M., 2011. Towards a more objective assessment of equine personality using behavioural and physiological observations from performance test training. Applied Animal Behaviour Science. 135, 277-285.

Krueger, K., 2007. Behaviour of horses in the 'round pen technique'. Applied Animal Behaviour Science. 104, 162-170.

Lesimple, C., Fureix, C., Menguy, H., Hausberger, M., 2010. Human direct actions may alter animal welfare, a study on horses (Equus caballus). PLOS ONE 5 (4): e10257.

Martin, P., and Bateson, P., 1993. Measuring Behaviour: An Introductory Guide. Cambridge University Press, UK.

McDonnell, S., 2003. A Practical Field Guide to Horse Behavior: The Equid Ethogram. The Blood Horse Inc., Lexington.

McDonnell, S.M., Haviland, J.C.S., 1995. Agonistic ethogram of the equid bachelor band. Applied Animal Behaviour Science. 43, 147-188.

McGreevy, P.D., McLean, A.N., 2010. Equitation Science. John Wiley and Sons Ltd. P. 43-51.

McGreevy, P.D., McLean, A.N., Warren-Smith, A.K., Waran, N., Goodwin, D., 2005. Defining the terms and processes associated with equitation. In: Proceedings of the First International Equitation Science Symposium, Melbourne, Australia. Pp 10-43.

McGreevy, P.D., Oddie, C., Burton, F.L., McLean, A.N., 2009. The horse-human dyad: Can we align horse training and handling activities with the equid social ethogram? The Veterinary Journal. 181, 12-18.

McLean, A.N., McGreevy, P.D., 2004. Training. In: McGreevy PD. Equine Behavior: A Guide for Veterinarians and Equine Scientists. Saunders, Edinburgh, UK. P291-311.

McLean, A., McLean, M., 2002. Horse Training the McLean Way: The Science Behind the Art. Australian Equine Behaviour Centre, Victoria, Australia. Pp 9-10.

Minero, M., Dassi, M., Martelli Canali, E., 2003. Behaviour and heart rate of therapeutic riding horses interacting with patients. In: Ferrante V. (Ed.) Proceedings of the $37^{\text {th }}$ International Congress of the International Society for Applied Ethology. Abano Terme, Italy. P54.

Minero, M., Tosi, M.V., Canali, E., Wemelsfelder, F., 2009. Quantitative and qualitative assessment of the response of foals to the presence of an unfamiliar human. Applied Animal Behaviour Science. 116, 74-81. 
Munsters, C.C.B.M., Visser, K.E.K., van den Broek, J., Sloet van Oldruitenborgh-Oosterbaan, M.M., 2012. The influence of challenging objects and horse-rider matching on heart rate, heart rate variability and behavioural score in riding horses. The Veterinary Journal. 192, 75-80.

Munsters, C.C.B.M., van den Broek, J., van Weeren, R., Sloet van Oldruitenborgh-Oosterbaan, M.M., 2013. The effects of transport, riot control training and night patrols on the workload and stress of mounted police horses. Applied Animal Behavour Science. 143, 52-60.

Peters, S.M., Bleijenberg, E.H., van Dierendonck, M.C., van der Harst, J.E., Spruijt, B.M., 2012. Characterization of anticipatory behaviour in domesticated horses (Equus caballus). Applied Animal Behaviour Science. 138, 60-69.

Pierard, M., Hall, C., König von Borstel, U., Averis, A., Hawson, L., McLean, A., Nevison, C., Visser, K., McGreevy, P., 2015. Evolving protocols for research in equitation science. Journal of Veterinary Behavior. Doi: 10.1016/j.jveb.2015.01.006.

Quick, J.S., Warren-Smith, A.K., 2009. Preliminary investigations of horses' (Equus caballus) responses to different bridles during foundation training. Journal of Veterinary Behaviour. 4, 169-176.

Rietmann, T.R., Stuart, A.E.A., Bernasconi, P., Stauffacher, M., Auer, J.A., Weishaupt, M.A., 2004. Assessment of mental stress in warmblood horses: heart rate variability in comparison to heart rate and selected behavioural parameters. Applied Animal Behaviour Science. 88, 121-136.

Rhodin, M., Johnston, K., Roethlisberger Holm, K., Wennerstrand, J., Drevemo, S., 2005. The influence of head and neck position on kinematics of the back in riding horses at the walk and trot. Equine Veterinary Journal. 37, 7-11.

Rivera, E., Benjamin, S., Nielsen, J., Shelle, A.J., Zanella, A.J., 2002. Behavioral and physiological responses of horses to initial training: the comparison between pastured versus stalled horses. Applied Animal Behaviour Science. 78, 235-252.

Rothmann, J., Christensen, O.F., Sondergaard, E., Ladewig, J., 2014. Behavior observation during conformation evaluation at a field test for Danish warmblood horses and associations with rideability and performance traits. Journal of Equine Veterinary Science. 34, 288-293.

Sighieri, C., Tedeschi, D., De Andreis, C., Petri, L., Baragli, P., 2003. Behaviour patterns of horses can be used to establish a dominant-subordinate relationship between man and horse. Animal Welfare. 12, 705708.

Søndergaard, E., Ladewig, J., 2004. Group housing exerts a positive effect on the behaviour of young horses during training. Applied Animal Behaviour Science. 87, 105-118.

Valera, M., Bartolomé, E., Sánchez, M.J., Molina, A., Cook, N., Schaefer, A., 2012. Changes in eye temperature and stress assessment in horses during show jumping competitions. Journal of Equine Veterinary Science. 32, 827-830.

Visser, K.E., Karlas, K., van Deurzen, I., Workel, L., van Reenen, K., 2010. Experts' assessment of temperament in sport horses. Journal of Veterinary Behaviour. 5, 214-215. 
Visser, E.K, Van Dierendonck, M., Ellis, A., Rijksen, C., Van Reenen, C.G., 2009. A comparison of sympathetic and conventional training methods on response to initial horse training. The Veterinary Journal. 181, 48-52.

von Borstel, U., Duncan, I.J.H., Shoveller, A.K., Merkies, K., Keeling, L.J., Millman, S.T., 2009. Impact of riding in a coercively obtained Rollkur position on welfare and fear of performance horses. Applied Animal Behaviour Science. 116, 228-236.

Waite, K., 2014. Measurement of prosocial and antisocial behavior among youth equestrian competitors, Chapter 3: Quantifying aggressive riding behavior of youth barrel racers and conflict behaviors of their horses. Ph.D. Dissertation, Michigan State University.

Waring, G.H., 2003. Horse Behaviour. $2^{\text {nd }}$ Edition. Noyes Publications. William Andrew Publishing, NY. Wathan, J., Burrows, A.M., Waller, B.M., McComb, K. 2015. EquiFACS: The Equine Facial Action Coding System. PLoS ONE. DOI: 10.1371/journal.pone.0131738

Weeks, J., 1996. Equine agitation behaviours. Equine Practice. 18, 23-24.

Wemelsfelder, F., Hunter, E.A., Mendl, M.T., Lawrence, A.B., 2000. The spontaneous qualitative assessment of behavioural expressions in pigs: first explorations of a novel methodology for integrative animal welfare measurement. Applied Animal Behaviour Science. 67, 193-215.

Wemelsfelder, F., Hunter, T.E.A., Mendl, M.T., Lawrence, A.B., 2001. Assessing the 'whole animal': a free choice profiling approach. Animal Behaviour. 62, 209-220.

Williams, L.R., Warren-Smith, A.K., 2010. Conflict responses exhibited by dressage horses during competition. Journal of Veterinary Behavior. 5, 215.

Yarnell, K., Hall, C., Billett, E., 2013. An assessment of the aversive nature of an animal management procedure (clipping) using behavioral and physiological measures. Physiology and Behavior. 118, 32-39.

Young, T., Creighton, E., Smith, T., Hosie, C., 2012. A novel scale of behavioural indicators of stress for use with domestic horses. Applied Animal Behaviour Science. 140, 33-43.

Zebisch, A., May, A., Reese, S., 2013. Effect of different head-neck positions on physical and psychological stress parameters in the ridden horse. Journal of Animal Physiology and Animal Nutrition. DOI: 10.1111/jpn.12155

Zetterqvist Blokhuis, M., Aronsson, A., Hartmann, E., Van Reenen, C.G., Keeling, L., 2008. Assessing the rider's seat and horse's behaviour: Difficulties and perspectives. Journal of Applied Animal Welfare Science. 11, 191-203. 